\section{Financial Crisis and Impairment Recognition in Non-Financial Assets}

\author{
Cristina Gaio ${ }^{1}$ \\ Tiago Gonçalves ${ }^{1}$ \\ Anabela Pereira ${ }^{2}$
}

\begin{abstract}
Purpose - To analyse the impact of the financial crisis on the recognition of non-financial asset impairments in European listed companies.

Theoretical framework - The study explores the impact of the theory of measuring the economic value of non-financial assets on managers' decisions to recognize impairments, especially in the context of an economic crisis.
\end{abstract}

Design/methodology/approach - Logit and ordinary least squares models were estimated to analyse the probability of recognition and the amount of impairment recognized, respectively, over a 10 -year period.

Findings - The results show that European companies recognized less impairments during the crisis, including companies in countries that have used external financial aid, suggesting that managers may use impairment recognition as a way of practicing earnings management.

Research Practical \& Social implications - The results are of interest to several stakeholders, namely: creditors, investors, financial market regulators, entities that prepare and oversee the application of accounting and auditing standards, and ultimately European leaders in terms of structural reforms and investor protection laws.

Originality/value - The study contributes to the literature that analyses the impact of the financial crisis on the recognition of impairments in non-financial assets and, in particular, in the context of greater financial fragility. It also contributes to the literature on the use of discretion in the recognition of impairments and earnings management practices. Moreover, it adds to the theoretical debate regarding the principles of measurement in the context of impairment, and how this may affect assessments of the economic values of non-financial assets.

Keywords - financial crisis; European listed companies; non-financial asset impairments; earnings management

\section{Advance/CSG, ISEG - Lisbon School of Economics \& Management: Universidade de Lisboa, Portugal}

2. ISEG - Lisbon School of Economics \& Management: Universidade de Lisboa, Portugal

\section{How to cite:}

Gaio, C., Gonçalves, T., Pereira, A. (2021). Financial Crisis and Impairment Recognition in Non-Financial Assets. Revista Brasileira de Gestão de Negócios, 22(1), firstpage-lastpage.
370

Received on:

08/06/2019

Approved on:

$12 / 23 / 2020$

Responsible Editor:

Prof. Dr. Ilídio Lopes

\section{Evaluation process:}

Double Blind Review

\section{Reviewers:}

Ana Fialho; Maria do Céu Gaspar Alves.

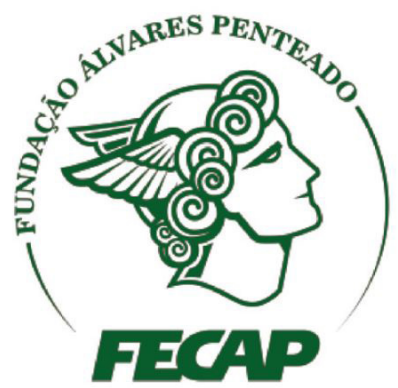

Revista Brasileira de Gestáo de Negócios

https://doi.org/10.7819/rbgn.v23i2.4108 


\section{Introduction}

During 2008 and 2009, European companies faced probably the worst financial crisis ever. The 20082009 financial crisis, commonly referred to as the subprime crisis, led to strong turbulence in the financial markets and a sharp contraction of the economy, considered to be the largest economic contraction since the Second World War (Barth \& Landsman, 2010). This crisis had a heavy impact on the European business environment, being considered by many as the worst crisis since the Great Depression of 1930 (Gunn, Khurana, \& Stein, 2018).

Financial crises affect not only the financial sector, but also the business sector. According to Kousenidis, Ladas and Negakis (2013), financial crises affect firms through two interacting pathways: unfavourable macroeconomic conditions lead to a decline in firms' sales and level of operational performance; and the financial collapse of banking and capital markets limits financing opportunities by reducing firms' liquidity. Although financial institutions may have been the most affected by the 2008-2009 financial crisis, the effects of the crisis also spread to non-financial firms (Gonçalves, Gaio, \& Robles, 2018). In this period, many companies had to review their businesses, as well as the value of their assets, since these might not have been reflecting their true economic value.

In fact, in periods of economic recession, there is a high probability of rapid deterioration of assets and the decision to recognize impairments is of the utmost importance, as negative changes in the economy (such as a financial crisis) are one of the external indications referred to in the provisions of IAS 36 - Impairment of Assets, which may imply lost economic return capacity of assets.

The consequences of macroeconomic changes, specifically turbulent economic periods, on the quality of accounting information are still poorly explored (Filip \& Raffournier, 2014). Studies analysing the impact of the financial crisis on the recognition of impairments in non-financial companies and, in particular, in nonfinancial assets, remain scarce. Examples of these scarce studies are those of Vanza, Wells and Wright (2011), Wirtz (2013), Yammine and Olivier (2014) and Zhang (2011). Additionally, most of the literature focuses on analysing goodwill impairments, and the remaining non-financial assets do not tend to be investigated, despite their predominance among corporate assets. There are even fewer studies analysing companies in countries with greater financial fragility, which, as such, may feel the negative impact of a financial crisis on their performance levels and on the economic value of their assets more intensely. Examples of such studies are those of Albuquerque, Almeida and Queiroz (2011), Izzo, Luciani and Sartori (2013) and Sant'Ana, Gonçalves, Guerreiro and Nobre (2016). On the other hand, the scarce studies there are do not present consensual conclusions.

Thus, this study has two major objectives. First, it aims to analyse whether European listed companies recognized more impairments in non-financial assets during the 2008-2009 financial crisis, and if, when recognizing impairments, the amount considered, i.e. the magnitude of the impairment, was higher due to the negative consequences of the crisis. Secondly, it seeks to analyse the behaviour of companies from countries that resorted to external financial aid, specifically Greece, Italy, Ireland, Portugal and Spain (the so-called "PIIGS"). These objectives may be framed in the measurement theory, as they consider the intended effects (or not) of the recognition and measurement of impairments, in the context of a financial crisis, where the relevance of financial statements is subject to greater volatility.

A sample was analysed consisting of 1383 listed companies from 14 European countries and covering a 10-year period (2005 to 2014). In terms of methodology, logit and ordinary least squares (OLS) models were estimated to analyse the probability of recognition and the amount of impairments recognized, respectively, both for the total sample and for the two subgroups of countries: intervention and non-intervention.

The results indicate that during the financial crisis European firms recognized fewer impairments of non-financial assets, which may suggest that managers avoided recognizing impairments in order to perform better, using the discretion underlying the recognition and calculation of impairments to manage earnings upwards and thus mitigate the low performance characteristic in times of crisis.

Through the results obtained it is also possible to conclude that companies whose countries resorted to financial aid also recognized fewer impairments during the crisis period and that, unlike in the non-intervention countries, the level of enforcement of accounting and 
auditing standards was positively associated with the magnitude of impairments recognized.

The research findings are thus relevant both at the theoretical level and at the level of financial reporting practices. From a theoretical point of view, the evidence found allows for an understanding of the unintended effects of the measurement theory, regarding the recognition of impairments. Thus, in terms of measurement theory and the disclosure of relevant financial statements for the purpose of economic decisions, we found evidence of manager discretion that limits this relevance of financial information, especially when economic values are more volatile. We also contribute to the theoretical debate concerning the principles of measurement in the context of impairment, and how this may affect assessments of the economic values of non-financial assets. From a practical point of view, we contribute with positivist evidence that will inform regulators and investors about the economic relevance (or loss of this) of financial information on impairments, particularly in a context of greater volatility in the economy.

This study also contributes to the literature that analyses the impact of financial crises on the quality of financial reporting in general, and on the recognition of asset impairments in particular, essentially for two reasons: (1) most studies analyse the impact of the crisis on financial assets or goodwill (Carvalho, Rodrigues, \& Ferreira, 2013; Glaum, Landsman, \& Wyrwa, 2015; Zhang, 2011), whereas we analyse the impact on nonfinancial, tangible and non-tangible assets; (2) we analyse the impact of the crisis on a particular set of countries with greater financial fragility, i.e. the intervention countries. We also expect to contribute to the literature that analyses the use of asset impairment recognition in earnings management practices.

This study is divided into five sections. The second section provides a brief literature review, where we provide evidence of the main studies that support this research. In the third section the hypotheses of the study are formulated, the sample is described and the methodology adopted is presented. Section four presents and discusses the results obtained. Finally, the last section presents the main conclusions, limitations and possible suggestions for future research.

\section{Literature Review}

\section{I Impairment of assets and accounting information quality in the context of a financial crisis}

The accounting concept of "impairment" can be defined as a reduction or loss of the recoverable value of an asset that should lead to an adjustment of its value to reflect its real economic return capacity. Companies must perform impairment tests whenever there is any internal or external event where assets may have lost economic value, with the exception of indefinite life intangible assets, which must be tested annually. Impairment losses must be recognized in the event that the book value of assets is greater than the estimated recoverable amounts. In other words, this procedure prevents assets from being overstated in the financial statements and underlies the objective of measurement theory to provide relevant information for the decision-making of the different users of financial information (Gonçalves \& Coelho, 2019; Larson, 1969).

However, there is evidence of some conditional conservatism in the recognition of impairments in European listed companies, this being less expressive in countries where the effectiveness of institutions and the level of disclosure is lower (Amiraslani, Iatridis, \& Pope, 2013; Pinto, Gaio, \& Gonçales, 2019). In fact, in a study covering 235 European listed companies relating to 2011, the European Securities and Markets Authority (2013) concluded that few companies recognize goodwill impairment losses (only 36\%), with recognition for other intangible assets being even more limited.

On the other hand, the fact that recognizing impairments and calculating the amount to be recognized involves value judgements and the use of estimates creates opportunities for managers to practise earnings management. There is empirical evidence that managers manage earnings by recognizing impairment losses and their respective reversals in subsequent periods (Duh, Lee, \& Lin, 2009; Riedl, 2004). Earnings management through the recognition of excessive impairment losses and subsequent reversal may thus negatively affect the quality of the information reported by companies (Pinto et al., 2019).

The use of impairment recognition and its impact on accounting information quality may be even more evident in periods of financial crisis. In fact, the 
high volatility in financial markets and the substantial drop in company profitability and share values, which usually occur in periods of crisis, can cause losses in the economic value of assets and the need for recognition of impairment losses, with a subsequent negative impact on reported net income (Vanza et al., 2011). In periods of financial crisis, due to the increased asymmetry of information, assets tend to generate lower cash flows than expected, an effect that reinforces the recording of asset impairment (Amiraslani et al., 2013; Gonçalves, Gaio, \& Lélis, 2020). Thus, a financial crisis can be considered as an indicator of impairment, since there may be a tendency for companies' assets to deviate from their fundamental value and not reflect their true value.

However, based on the discretion underlying impairment calculations, companies may take advantage of the time of crisis, and the greater market tolerance of low results, to recognize more impairments than necessary, enabling them to show to the market a slight recovery in the post-crisis period as they no longer have to recognize more impairments and/or reverse those they previously recognized in excess (Masruki \& Azizan, 2012). Hassine and Jilani (2017) find evidence that French companies took advantage of the financial crisis to use goodwill impairment recognition to practise earnings management techniques such as income smoothing and big bath accounting. Also, based on an international sample, Glaum et al. (2015) conclude that there is scope for practising earnings management through the recognition of goodwill impairment losses in a context of financial crisis, even in countries with a rigorous level of enforcement in terms of the application of accounting and auditing standards.

\subsection{The 2008-2009 financial crisis and the recognition of impairments}

The 2008-2009 financial crisis, also known as the subprime crisis, was triggered by the bankruptcy of the US investment bank Lehman Brothers, which led to strong turbulence in the financial markets and to the spread of the crisis to many countries (Bordo, 2008). This caused a sharp contraction of the economy, both in the last months of 2008 and in 2009, representing the largest economic contraction since World War II (Barth \& Landsman, 2010). In fact, this crisis had a strong impact on the European business environment and is considered by many as the worst crisis since the Great Depression of 1930 (Gunn et al., 2018).

Amiraslani, Iatridis and Pope (2013) refer to a study conducted by Ernst \& Young in 2010 on 60 European listed companies, which suggests that the increased financial instability experienced in Europe at the end of the first decade of this century may have contributed to the recognition of impairments. This is due to the high number of companies that reassessed their impairment test procedures, models and assumptions in order to reflect the lost economic value of their assets in a timely manner.

However, regarding goodwill, which is one of the most studied assets in the literature in terms of impairments, a study by PricewaterhouseCoopers (2011) reveals that less than half of European listed companies (about 40.1\%) recognized impairment losses in goodwill in 2009. This result was not expected as, in periods of crisis, there is greater uncertainty and companies have to review their business plans and reduce their estimates of assets. Therefore, a greater recognition of impairments would have been expected, also due to the acquisitions that were made in previous years, when estimates of future cash flows were higher. Another conclusion of this study is that during the crisis period companies resorted to the discretion underlying impairment tests, with the aim of securing their market position and thus achieving the desired results, capital positions and financial ratios.

Of the still scarce studies that analyse the impact of the crisis on the recognition of impairments in non-financial assets, most do not find evidence of a positive association. Vanza et al. (2011) find no evidence that asymmetric information led to asset impairment recognition in Australian listed companies during the period from 2007 to 2009. Also, Wirtz (2013) shows that few companies recognized asset impairment losses during the financial crisis. The author also reveals that during the crisis auditors advised managers to recognize small impairment losses and more frequently, due to the greater scrutiny of financial statements.

Yammine and Olivier (2014) study the impact of the financial crisis in terms of the recognition and magnitude of impairments, in a sample composed of listed companies from 17 European countries, for the time interval 2005-2011. The authors show that in the crisis period there was a decrease in the recognition of impairments, despite there being an increase in their 
magnitude. They argue that during the crisis period managers tended to resort to practising earnings management, in order to achieve a certain strategic objective and not show underperformance, and as such, avoid the recognition of asset impairments. They also concluded that, during the crisis, companies from countries with low levels of governance indicators, such as rule of law, legal transparency, quality of regulations, government effectiveness, and corruption index, decreased the recognition of impairment in order to prevent a reduction in results, which were already below normal due to the effect of the crisis. In turn, in the group of countries with a high level of governance indicators, there was an increase in the magnitude of asset impairments, as a way for companies to create reserves in the post-crisis period.

In turn, when analysing which factors led to the recognition of goodwill impairments, in a sample of listed companies from 21 countries covering the period from 2005 to 2011, Glaum et al. (2015) conclude that the timely recognition of impairments is associated with the level of application of accounting and auditing standards (enforcement). That is, companies in countries with a higher level of enforcement tend to recognize impairments in a timelier manner (before, during and after the crisis). On the other hand, firms in countries with a low level of enforcement tend to postpone the recognition of impairments. In addition, the authors conclude that there is room for earnings management, even in countries with a strict level of enforcement.

Zhang (2011) also analyses the recognition of impairments in goodwill in listed companies in Germany and the United Kingdom, during the period from 2005 to 2010. The author concludes that during the crisis companies were less likely to recognize impairments in order to show better results and that the main determinant of the recognition of impairments was the companies' level of performance, measured by return on assets. More profitable companies tended to recognize fewer impairments and in smaller magnitudes. This can be explained by the fact that managers recognize impairments in order to achieve less unfavourable results.

The 2008-2009 financial crisis did not affect the different Eurozone countries in the same way and in some of them contributed to the development of a sovereign debt crisis (Huang, 2013). A sovereign debt crisis is mainly characterised by a reduction in the amount of credit available in countries and the existence of austerity policies. Due to high budget deficit and public debt levels, some countries, such as Greece, Italy, Ireland, Portugal and Spain, had to seek financial assistance from international institutions.

From 2010, the European Union (EU), the International Monetary Fund (IMF) and the European Central Bank (ECB) started to provide financial assistance to some countries, the so-called bailout countries. Greece was the first country to request assistance in 2010, followed by Ireland. The following year it was Portugal and Italy's turn, with Spain requesting help in 2012.

Analysing the recognition of impairments in non-financial assets by Portuguese listed companies in 2008, Albuquerque et al. (2011) verify that there were as many companies that recognized impairments as those that did not $(47.6 \%$ against $52.4 \%$ of the sample, respectively) and that most impairments were recognized in the last quarter of the financial reporting period, as a consequence of possible earnings management. In addition, when analysing the recognition of impairments in Portuguese and Spanish listed companies, Sant'Ana et al. (2016) found an income smoothing effect through impairments, which was more pronounced in IBEX35 entities.

Carvalho et al. (2013) study goodwill impairment losses in Portuguese listed companies from 2005 to 2012 in order to assess whether the 2008 economic crisis increased the frequency and magnitude of impairment losses. The results suggest that more profitable companies tended to recognize less goodwill impairment losses due to earnings management, while companies with negative results and lower goodwill are the ones that recognized more impairment losses. In addition, the results suggest that the financial crisis did not lead to a significant increase in goodwill impairment losses. Regarding the frequency of goodwill impairment losses, in 2011 and 2012 there was a higher number of these losses recorded, which suggests that recognition of impairments was not higher during the crisis but rather after three years. This is because the decision to recognize impairments may depend on economic and financial factors as well as management interests. Hayn and Hughes (2006) also conclude that impairment losses are only recognized three or four years after the respective impairment, but this can extend up to ten years.

In turn, when analysing listed Italian companies in the time interval 2007-2011, Izzo et al. (2013) found that in the first year of the crisis (2008) about $43 \%$ of the sample companies recognized goodwill impairment 
losses, while in the previous year only 19\% had done so. In 2009 , approximately $22 \%$ of the companies recorded a goodwill impairment loss, while in 2010 this percentage increased to $35 \%$, and in 2011 it rose to approximately $60 \%$, the highest value for the period analysed. In terms of the impairment ratio, which is defined by the authors as the ratio between the goodwill impairment loss and the book value of goodwill, the value increased from $1.73 \%$ in 2008 to $23 \%$ in 2011.

In short, although there are few studies that address the recognition of impairments in non-financial assets other than goodwill, especially in countries with greater financial fragility, such as the intervention countries, there is some evidence that the recognition of impairments can be used as a way to manage earnings in the context of a financial crisis. This therefore jeopardizes the objective of the measurement theory of providing relevant information for the decision-making process.

\subsection{Research hypotheses}

Although there are already studies that analyse the recognition of impairments of non-financial assets, there are still few that study the possible impact of the last global financial crisis, and the results found are mixed. Additionally, most of these studies analyse one asset in particular: goodwill. Wirtz (2013) and Zhang (2011) argue that in periods of crisis firms tend to recognize less or even avoid recognizing asset impairments.

Yammine and Olivier (2014) highlight that during a financial crisis the recognition of asset impairments can be used by managers as a means to achieve their strategic objectives. Managers would be expected not to recognize impairments so as not to worsen the low performance that is characteristic of times of crisis, and to thus convey the image that they are performing better than they would if they recognized impairment losses. Thus, the first study hypothesis is formulated as follows:

H1: During the financial crisis, firms avoided recognizing asset impairments.

The discretionary decision to recognize impairments involves not only their postponement (avoiding their recognition in moments of crisis), but also a reduction in the magnitude of impairments when they are recognized. Thus, we formulate an extension of Hypothesis 1 with regard to the magnitude of the impairments recognized:
H1A: During the financial crisis, firms recognized a smaller magnitude of asset impairments.

In addition, we intend to analyse whether, during the crisis, companies in countries receiving financial aid also avoided recognizing asset impairments, given that these countries suffered the most from the crisis. Thus, based on studies that focus on some of the intervention countries, namely those of Albuquerque et al. (2011), Carvalho et al. (2013) and Izzo et al. (2013), which found that there were few companies that recognized impairments in assets during the crisis, and that some companies tended to postpone this recognition to the post-crisis period, the second hypothesis studied will be:

$\mathrm{H} 2$ : During the financial crisis, firms whose countries received financial aid avoided recognizing asset impairments.

\section{Data and Methodology}

\section{I Data collection and sample description}

The firm-level financial data were collected from the Thomson Reuters database, while the macroeconomic variables (GDP and inflation) were taken from the Pordata database.

As in the study by Filip and Raffournier (2014), which analyses the impact of the financial crisis on earnings management practices in European listed companies, 2008 and 2009 are considered to be the crisis period, as it was in this period that there was the greatest turbulence in financial markets and the biggest economic contraction (Barth \& Landsman, 2010; Bartram \& Bodnar, 2009; Zhang, 2011), as shown in Figure 1. This decision makes our results directly comparable with other studies using the same crisis period.

The sample is composed of listed companies from $14 \mathrm{EU}$ member states, covering the window from 2005 to 2014 . The study period starts in 2005 , since it was from January of that year that it was mandatory for all listed and consolidated companies in the EU to adopt the International Financial Reporting Standards. This guarantees that all the companies analysed prepare their financial statements according to the same standards and that the results obtained will not be affected by regulatory diversity between countries. Additionally, this time window enables a balance between the pre-crisis, crisis and post-crisis periods. 
Financial sector companies were excluded from the sample given the specificities of their operations and financial reporting. Firms with insufficient data were also excluded from the sample. Thus, the final sample was composed of 1,383 companies and 13,830 companyyear observations.

Tables 1 and 2 present the composition of the sample by country and by activity sector, respectively. The most representative countries in the sample are the United Kingdom with $21.33 \%$ of the total number of firms, followed by France with $18.73 \%$ and Germany with $15.11 \%$.

In terms of sectors, the most representative are industry $(23.86 \%)$, cyclical consumption $(22.49 \%)$, technology (13.23\%) and basic materials (12.58\%).

\subsection{Models and variables}

Based on the work of Yammine and Olivier (2014), two empirical models were developed: a logit regression model (1) and an OLS regression model (2):

$$
\begin{aligned}
& \text { IMPDUM }_{i, \mathrm{t}}=\beta_{0}+\beta_{1} \text { CRISIS }_{\mathrm{i}, \mathrm{t}}+\beta_{2} \text { SIZE }_{\mathrm{i}, \mathrm{t}}+\beta_{3} \mathrm{DEBT}_{\mathrm{i}, \mathrm{t}}+ \\
& \beta_{4} \mathrm{ENF}_{\mathrm{i}, \mathrm{t}}+\beta_{5} \mathrm{GDP}_{\mathrm{i}, \mathrm{t}}+\beta_{6} \mathrm{INF}_{\mathrm{i}, \mathrm{t}}+\beta_{7} \text { COUNTRY }_{\mathrm{i}}+\beta_{7} \mathrm{SET}_{\mathrm{i}}+\varepsilon_{\mathrm{i}, \mathrm{t}}
\end{aligned}
$$

RACIOIMP $_{\mathrm{i}, \mathrm{t}}=\beta_{0}+\beta_{1}$ CRISIS $_{\mathrm{i}, \mathrm{t}}+\beta_{2}$ SIZE $_{\mathrm{i}, \mathrm{t}}+\beta_{3}$ DEBT $_{\mathrm{i}, \mathrm{t}}+\beta_{4} \mathrm{ENF}_{\mathrm{i}, \mathrm{t}}+$ $\beta_{5}$ EBTI $_{\mathrm{i}, \mathrm{t}}+\beta_{6} \mathrm{GDP}_{\mathrm{i}, \mathrm{t}}+\beta_{7} \mathrm{INF}_{\mathrm{i}, \mathrm{t}}+\beta_{8}$ COUNTRY $_{\mathrm{i}}+\beta_{9} \mathrm{SET}_{\mathrm{i}}+\varepsilon_{\mathrm{i}, \mathrm{t}}$

The dependent variable used in model (1), IMP DUM, represents the decision to recognize impairment or not. Thus, IMP DUM is a binary variable that assumes a value equal to 1 when the company recognizes an impairment in assets (tangible and intangible, including goodwill), and 0 otherwise.

The dependent variable used in model (2), IMP $R A C I O$, represents the magnitude of asset impairment, measured by the ratio between total asset (tangible and intangible, including goodwill) impairments, net of impairment reversals, and total underlying assets.

The variable of interest, CRISIS, is also a binary variable that takes a value equal to 1 if the observation of firm $\mathrm{i}$ in year t belongs to the crisis period, and 0 otherwise. In this study, following similar studies, the peak of the financial crisis corresponds to the interval between 2008 and 2009. Based on the results obtained

Table 1

\section{Sample composition by country}

\begin{tabular}{cccc}
\hline & $\begin{array}{c}\text { Num. } \\
\text { companies }\end{array}$ & $\begin{array}{c}\text { Num. } \\
\text { observations }\end{array}$ & \% total \\
\hline Austria & 32 & 320 & $2.31 \%$ \\
Belgium & 55 & 550 & $3.98 \%$ \\
Denmark & 47 & 470 & $3.40 \%$ \\
Finland & 64 & 640 & $4.63 \%$ \\
France & 259 & 2.590 & $18.73 \%$ \\
Germany & 209 & 2.090 & $15.11 \%$ \\
Greece & 26 & 260 & $1.88 \%$ \\
Ireland & 13 & 130 & $0.94 \%$ \\
Italy & 131 & 1.310 & $9.47 \%$ \\
Netherlands & 55 & 550 & $3.98 \%$ \\
Portugal & 27 & 270 & $1.95 \%$ \\
Spain & 65 & 650 & $4.70 \%$ \\
Sweden & 105 & 1.050 & $7.59 \%$ \\
United & 295 & 2.950 & $21.33 \%$ \\
Kingdom & & & \\
Total & $\mathbf{1 , 3 8 3}$ & $\mathbf{1 3 , 8 3 0}$ & $\mathbf{1 0 0 \%}$ \\
\hline
\end{tabular}

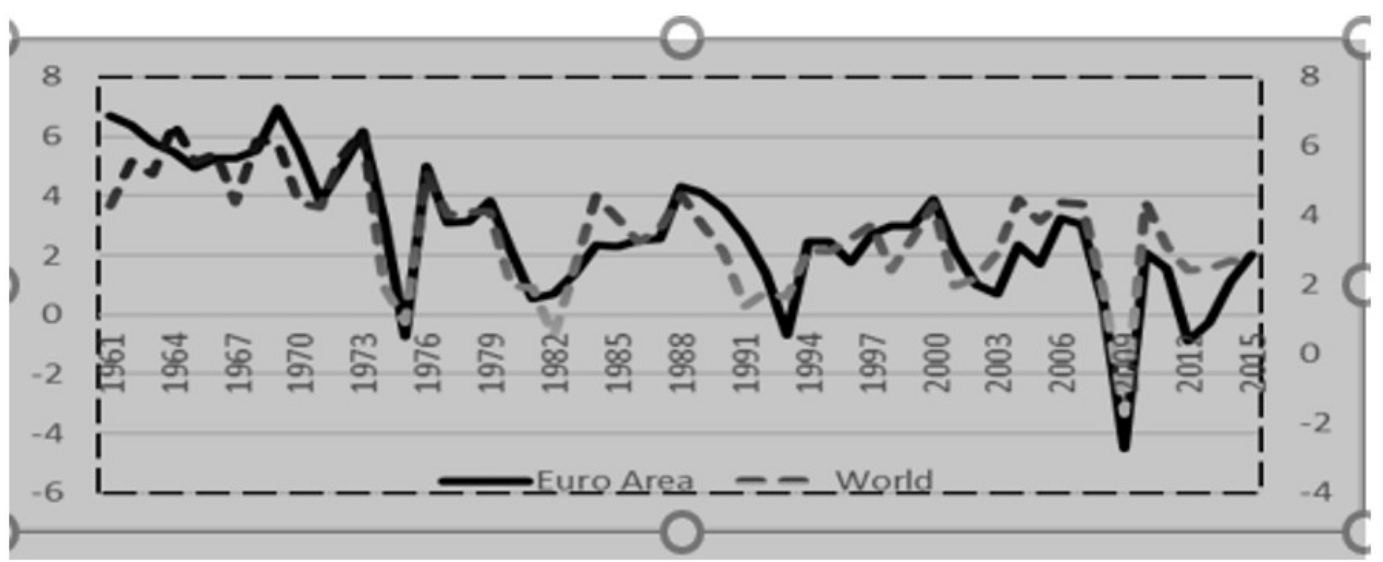

Figure 1. Annual GDP growth rates

Source: World Bank 
Table 2

\section{Sample composition by sector of activity}

\begin{tabular}{cccc}
\hline & $\begin{array}{c}\text { Num. } \\
\text { companies }\end{array}$ & $\begin{array}{c}\text { Num. } \\
\text { observations }\end{array}$ & \% Total \\
\hline Basic Materials & 174 & 1.740 & $12.58 \%$ \\
Cyclical & 311 & 3.110 & $22.49 \%$ \\
Consumption & & & \\
Non-cyclical & 118 & 1.180 & $8.53 \%$ \\
Consumption & & & \\
$\quad$ Energy & 88 & 880 & $6.36 \%$ \\
Health Care & 96 & 960 & $6.94 \%$ \\
Industry & 330 & 3.300 & $23.86 \%$ \\
Technology & 183 & 1.830 & $13.23 \%$ \\
Telecommunication & 35 & 350 & $2.53 \%$ \\
Services & & & \\
Utility Services & 48 & 480 & $3.47 \%$ \\
Total & $\mathbf{1 , 3 8 3}$ & $\mathbf{1 3 , 8 3 0}$ & $\mathbf{1 0 0 \%}$ \\
\hline
\end{tabular}

by Zhang (2011) and Yammine and Olivier (2014), which suggest that in crisis periods firms are less likely to recognize impairments, the sign of the coefficient of the CRISIS variable is expected to be negative.

The SIZE variable aims to control for the impact of firm size on impairment recognition, including the ability of the firm to apply more complex impairment testing procedures. Large companies have more resources to carry out more complex impairment calculations and tests and thus are more prepared to discover possible impairments and comply with regulatory requirements (AbuGhazaleh, Al-Hares, \& Roberts, 2011; Giner \& Pardo, 2015; Ramanna \& Watts, 2012; Sant'Ana et al., 2016). Additionally, several studies show that asset impairments are more likely to occur in large firms (Kvaal, 2005; Saastamoinen \& Pajunen, 2016). Thus, the sign of the coefficient of the SIZE variable is expected to be positive.

The $D E B T$ variable intends to control for the effect of the level of debt on the recognition of impairments. Previous studies suggest that the association between debt and asset impairment recognition can be both negative and positive. That is, on one hand, more indebted firms may avoid recognizing impairments with the aim of not violating debt contract covenants (Hassine \& Jilani, 2017; Ramanna \& Watts, 2012), given that if the covenants are violated the firm may face several consequences, such as a bad reputation, greater difficulty in obtaining loans and higher financing costs. On the other hand, firms with higher debt levels may be under tighter control by creditors and investors, leaving less room for earnings management in impairment decisions (Elliott \& Shaw, 1988; Korošec, Jerman, \& Tominc, 2016; Saastamoinen \& Pajunen, 2016; Strong \& Meyer, 1987), which may lead to higher impairment recognition. Thus, we have no expectation regarding the coefficient of the DEBT variable.

Regarding the EBTI variable, it represents the result that would be reported if the firm had not recognized impairments. Kvaal (2005) argues that the association between this variable and the recognition of impairments reflects earnings management. Similarly to in the study by Yammine and Olivier (2014), this variable is only included in model (2). Firms that have higher impairment-adjusted earnings are expected to recognize fewer asset impairments, because impairments are an item that reduces the firm's earnings.

In terms of institutional and macroeconomic variables, the real gross domestic product $(G D P)$ growth rate, the inflation rate $(I N F)$ and the level of enforcement of international accounting standards $(E N F)$ were included in the models. To measure the level of enforcement of international accounting standards, an index was created, based on the work of Preiato, Brown, and Tarca (2015) for 2008, which reflects the level of enforcement of accounting and auditing standards. As Preiato et al. (2015) state, this index may be more useful and have greater explanatory power than those usually used in the literature, in that it is more focused and enables countries to be differentiated according to their enforcement capacity in terms of accounting requirements.

In countries where the level of enforcement is higher, companies recognize asset impairments in a timelier and more frequent manner (Amiraslani et al., 2013; Glaum et al., 2015), which can be explained by the reduction in earnings management practices (Houqe, Van Zijl, Dunstan, \& Karim, 2012). Managers are encouraged to follow the expected accounting standards, and thus increase the accuracy of estimates and reduce analysts' uncertainty (Hope, 2003). Therefore, the higher the value of the enforcement index the more effective the enforcement practices are, and the higher the quality of information in financial reports. Assuming that firms may recognize more impairments than necessary in order to manage their earnings downwards (Yammine \& Olivier, 2014), and since a high level of enforcement may be associated with a reduction in earnings management practices, a high level of enforcement is expected to lead firms to write off 
the additional amount recorded as impairment that was above what would be economically necessary (Yammine \& Olivier, 2014). As such, we expect a negative coefficient for this variable.

Finally, the SET dummy variable was introduced, in order to control for the effect of different characteristics at the industry level, as well as the COUNTRY dummy variable, which serves to control for the effect of different characteristics at the country level. A summary of the description, calculation, expected sign and literature supporting the choice of the variables is presented in Appendix.

\section{Analysis of the results}

\section{I Descriptive statistics}

Table 3 presents the mean of the dependent and independent variables of the models for the crisis (2008 to 2009) and non-crisis (2005 to 2007 and 2010 to 2014) periods, for all firms (Panel A), for the firms in intervention countries (Panel B) and for the firms in non-intervention countries (Panel C).

In panel $A$ it can be seen that, on average, the value of asset impairments is higher in the crisis period.

Table 3

\section{Means by period}

\begin{tabular}{|c|c|c|c|c|}
\hline \multirow{2}{*}{ Variables } & \multicolumn{2}{|c|}{ Num. observations } & \multicolumn{2}{|c|}{ Mean } \\
\hline & Crisis & Non-Crisis & Crisis & Non-Crisis \\
\hline \multicolumn{5}{|c|}{ Panel A - Total } \\
\hline IMP (thousands $€$ ) & 2,766 & 11,064 & 283.061 & 262.331 \\
\hline RATIO IMP (\%) & 2,766 & 11,064 & 0.0222 & 0.0165 \\
\hline$S I Z E(\log )$ & 2,766 & 11,064 & 12.6951 & 12.6906 \\
\hline$D E B T(\%)$ & 2,766 & 11,064 & 0.2535 & 0.2291 \\
\hline$E B T I(\%)$ & 2,766 & 11,064 & -0.0150 & 0.0273 \\
\hline ENF (index) & 2,766 & 11,064 & 44.1786 & 44.1786 \\
\hline$G D P(\%)$ & 2,766 & 11,064 & -0.0217 & 0.0168 \\
\hline INF (\%) & 2,766 & 11,064 & 0.0212 & 0.0196 \\
\hline \multicolumn{5}{|c|}{ Panel B - Intervention countries } \\
\hline IMP (thousands $€$ ) & 524 & 2,096 & 178.352 & 301.158 \\
\hline RATIO IMP (\%) & 524 & 2,096 & 0.0082 & 0.0125 \\
\hline SIZE (log) & 524 & 2,096 & 13.4585 & 13.3668 \\
\hline$D E B T(\%)$ & 524 & 2,096 & 0.3191 & 0.3352 \\
\hline$E B T I(\%)$ & 524 & 2,096 & 0.0242 & 0.0478 \\
\hline ENF (index) & 524 & 2,096 & 41.0229 & 41.0229 \\
\hline$G D P(\%)$ & 524 & 2,096 & -0.0253 & 0.0036 \\
\hline INF (\%) & 524 & 2,096 & 0.0196 & 0.0202 \\
\hline \multicolumn{5}{|c|}{ Panel C - Non-intervention countries } \\
\hline IMP (thousands $€$ ) & 2,242 & 8,968 & 307.534 & 253.257 \\
\hline RATIO IMP (\%) & 2,242 & 8,968 & 0.0255 & 0.0174 \\
\hline SIZE (log) & 2,242 & 8,968 & 12.5167 & 12.5326 \\
\hline$D E B T(\%)$ & 2,242 & 8,968 & 0.2382 & 0.2043 \\
\hline$E B T I(\%)$ & 2,242 & 8,968 & -0.0241 & 0.0226 \\
\hline ENF (index) & 2,242 & 8,968 & 44.9162 & 44.9162 \\
\hline$G D P(\%)$ & 2,242 & 8,968 & -0.0208 & 0.0199 \\
\hline$I N F(\%)$ & 2,242 & 8,968 & 0.0216 & 0.0195 \\
\hline
\end{tabular}


The ratio of impairments also presents, on average, a higher value in the crisis period $(2.22 \%)$ in comparison with the non-crisis period (1.65\%).

In panel $\mathrm{B}$ it is found that companies in the intervention countries present, on average, a significantly lower value of asset impairments in the crisis period (around 69\%) than in the non-crisis period. During the crisis period, the intervention countries present an average impairment ratio of $0.82 \%$, while in the non-crisis period this group of countries presents an average of $1.25 \%$.

On the other hand, companies in non-intervention countries show higher average values in the crisis period, both in terms of amount and impairment ratio (Panel C).

Tests of equality of means of the dependent variables by period (crisis and non-crisis) and by country (intervention or non-intervention) were carried out. The results in Table 4 show that, for the IMP DUM variable, there are statistically significant differences

Table 4

\section{Mean test results1}

\begin{tabular}{cccl}
\hline & Obs & IMP DUM & RATIO IMP \\
\hline & Panel A-Means by period \\
\hline Crisis & 2,766 & 0.4128706 & 0.0221854 \\
Non-crisis & 11,064 & 0.3868402 & 0.0165009 \\
Difference & & 0.0260304 & 0.0056845 \\
p-value & & $\mathbf{0 . 0 1 2 7}$ & $\mathbf{0 . 2 8 7 0}$ \\
\hline
\end{tabular}

Panel B - Means by intervention and non-intervention countries

\begin{tabular}{crll}
\hline Intervention & 2,620 & 0.4908397 & 0.0116167 \\
$\begin{array}{c}\text { Non- } \\
\text { intervention }\end{array}$ & 11,210 & 0.3689563 & 0.0190451 \\
Difference & & & \\
p-value & & 0.1218834 & -0.0074284 \\
\hline
\end{tabular}

between the crisis and non-crisis periods, suggesting that the probability of companies recognizing impairments is higher in the crisis period.

Regarding the analysis of intervention versus non-intervention countries, the results also suggest that the differences are statistically significant at the level of the IMP DUM variable, with evidence that the firms in intervention countries tend to recognize more impairments.

Table 5 presents the matrix of correlations between the variables of the models. In general, the variables show a weak correlation, suggesting that there are no multicollinearity problems.

\subsection{Impact of crisis on impairment recognition and magnitude}

Table 6 summarizes the results obtained for two different specifications of models (1) and (2), with and without the inclusion of the $R O A$ variable, since the level of profitability is considered in the literature as an important determinant of impairment recognition.

We can see that when the dependent variable is IMP DUM, shown in columns 1 and 2, the CRISIS variable presents a statistically significant negative coefficient, which suggests that during the crisis period firms tended to reduce the recognition of asset impairments, thus validating $\mathrm{H} 1$.

The results also suggest that larger firms with higher debt levels were more likely to recognize asset impairments, which is consistent with the results obtained in previous studies (Glaum et al., 2015; Verriest \& Gaeremynck, 2009; Zhang, 2011).

In line with the literature, the coefficients of the institutional and macroeconomic variables suggest

Table 5

\section{Correlation matrix}

\begin{tabular}{|c|c|c|c|c|c|c|c|c|}
\hline & $I M P$ & RATIO IMP & $E N F$ & $S I Z E$ & $D E B T$ & $E B T I$ & $G D P$ & $I N F$ \\
\hline$I M P$ & 1.0000 & & & & & & & \\
\hline RATIO IMP & 0.0191 & 1.0000 & & & & & & \\
\hline$E N F$ & $0.0338^{* * *}$ & $0.0315^{* * *}$ & 1.0000 & & & & & \\
\hline$S I Z E$ & $0.1882^{* * *}$ & $-0.0673^{* * *}$ & $-0.0623^{* * *}$ & 1.0000 & & & & \\
\hline$D E B T$ & 0.0159 & $0.1741^{* * *}$ & $-0.0633^{* * *}$ & $0.0329^{* * *}$ & 1.0000 & & & \\
\hline$E B T I$ & 0.0080 & $0.3734^{* * *}$ & $-0.0330^{* * *}$ & $0.1455^{* * *}$ & $0.0895^{* * *}$ & 1.0000 & & \\
\hline$G D P$ & $-0.0243^{* * *}$ & -0.0100 & $0.0665^{* * *}$ & $-0.0474^{* * *}$ & $-0.0713^{* * *}$ & $0.0323^{* * *}$ & 1.0000 & \\
\hline INF & 0.0064 & 0.0021 & $0.2350^{* * *}$ & -0.0213 & $-0.0223^{* * *}$ & $-0.0239^{* * *}$ & $0.1690^{* * *}$ & 1.0000 \\
\hline
\end{tabular}

Note: ${ }^{\star \star \star} 1 \%$ significance level 
a negative association between the probability of recognizing impairments and the levels of audit and accounting standards enforcement, economic growth, and inflation.

When the dependent variable is the magnitude of recognized impairments, RATIO IMP, shown in columns 3 and 4, the results suggest no statistically significant association between impairment recognition and the crisis, thus not validating hypothesis H1A. Consistently with the results obtained by Yammine and Olivier (2014), the coefficient of the CRISIS variable presents a positive sign, suggesting that during the crisis period companies recognized a higher amount of impairments, but it is not statistically significant.
The inclusion of the $R O A$ variable (ratio of net income to total assets) in both models, shown in columns 2 and 4, which is considered by many to be one of the main determinants of impairment recognition (Glaum et al., 2015; Zhang, 2011), does not change the previous findings. That is, the probability of recognizing losses during the crisis decreased and there is no evidence that firms recognized higher amounts of impairments in the crisis period. The higher the profitability of the firm, the lower the probability that firms will recognize impairments and the lower the magnitude of the recognized impairments, as according to Zhang (2011).

Finally, it should be noted that the adjusted $\mathrm{R}^{2}$ of model (2), shown in column 4, increases substantially

Table 6

Impact of the financial crisis on the recognition and magnitude of impairments

\begin{tabular}{|c|c|c|c|c|}
\hline \multirow{2}{*}{ Variables } & \multicolumn{2}{|c|}{ IMP DUM } & \multicolumn{2}{|c|}{ RATIO IMP } \\
\hline & (1) & (2) & (3) & (4) \\
\hline \multirow[t]{2}{*}{ Constant } & -0.9673 & -1.1733 & 0.1998 & 0.0721 \\
\hline & $(0.0000)$ & $(0.0000)$ & $(0.0860)$ & $(0.0310)$ \\
\hline \multirow[t]{2}{*}{ CRISIS } & -0.4905 & -0.4926 & 0.0001 & 0.0035 \\
\hline & $(0.0000)$ & $(0.0000)$ & $(0.9790)$ & $(0.3670)$ \\
\hline \multirow[t]{2}{*}{ SIZE } & 0.1418 & 0.1590 & -0.0169 & -0.0033 \\
\hline & $(0.0000)$ & $(0.0000)$ & $(0.0630)$ & $(0.0040)$ \\
\hline \multirow[t]{2}{*}{ DEBT } & 0.1328 & 0.0736 & 0.1218 & -0.0830 \\
\hline & $(0.0110)$ & $(0.1810)$ & $(0.0690)$ & $(0.1990)$ \\
\hline \multirow[t]{2}{*}{ EBTI } & & & 0.2472 & 0.4725 \\
\hline & & & $(0.2510)$ & $(0.0000)$ \\
\hline \multirow[t]{2}{*}{ ROA } & & -0.4755 & & -0.4832 \\
\hline & & $(0.0000)$ & & $(0.0000)$ \\
\hline \multirow[t]{2}{*}{ ENF } & -0.0180 & -0.0191 & 0.0015 & 0.0003 \\
\hline & $(0.0000)$ & $(0.0000)$ & $(0.0080)$ & $(0.0070)$ \\
\hline \multirow[t]{2}{*}{ GDP } & -0.1583 & -0.1554 & -0.0035 & -0.0013 \\
\hline & $(0.0000)$ & $(0.0000)$ & $(0.0060)$ & $(0.0140)$ \\
\hline \multirow[t]{2}{*}{ INF } & -0.0485 & -0.0492 & -0.0013 & -0.0021 \\
\hline & $(0.0140)$ & $(0.0130)$ & $(0.5090)$ & $(0.0350)$ \\
\hline Dummy Country & Yes & Yes & Yes & Yes \\
\hline Dummy Sector & Yes & Yes & Yes & Yes \\
\hline Obs. & 13.830 & 13.830 & 13.830 & 13.830 \\
\hline Pseudo $\mathbf{R}^{2}$ & 0.067 & 0.0703 & & \\
\hline Adjusted $\mathbf{R}^{2}$ & & & 0.1832 & 0.8335 \\
\hline F-statistic & & & 2.65 & 9.71 \\
\hline p-value & $(0.0000)$ & $(0.0000)$ & $(0.0000)$ & $(0.0000)$ \\
\hline
\end{tabular}

Note: p-values in brackets 
when the $R O A$ variable is introduced, which reveals the strong explanatory power of the firm's performance level in relation to the magnitude of impairments recognized by European firms (Gonçalves, Gaio, \& Santos, 2019).

In sum, the results suggest that there is a lower probability for the recognition of impairments in periods of crisis, but it is not possible to conclude that the crisis had an impact on the magnitude of impairment losses recognized.

\subsection{Intervention versus non-intervention countries}

In order to analyse whether the probability of recognition and magnitude of impairments were affected by the crisis differently in countries that requested financial assistance, we divided the sample into two groups, intervention and non-intervention countries, and estimated models (1) and (2) for each group. Table 7 summarizes the results obtained.

The results are broadly consistent with those previously reported. In terms of impairment recognition, shown in columns 1 and 3, the coefficient of CRISIS is negative and statistically significant, suggesting that during the crisis firms tended to recognize fewer impairment losses, both in the intervention and nonintervention countries. This coefficient is, however, higher in the group of intervention countries, which may suggest that firms whose countries received financial aid were less likely to recognize asset impairments, thus validating $\mathrm{H} 2$.

\subsection{Discussion of the results}

The results obtained suggest that firms may choose not to recognize impairments in order to report "better" results, offsetting the economic difficulties experienced during a crisis and their negative impact on results. This is consistent with the results obtained by Zhang (2011) for German and UK listed firms, by Vanza et al. (2011) for German listed firms and by Yammine and Olivier (2014) for a set of European listed firms.

Table 7

Intervention versus non-intervention countries

\begin{tabular}{|c|c|c|c|c|}
\hline \multirow{3}{*}{ Variables } & \multicolumn{2}{|c|}{ Intervention countries } & \multicolumn{2}{|c|}{ Non-intervention countries } \\
\hline & IMP DUM & RATIO IMP & IMP DUM & RATIO IMP \\
\hline & $(1)$ & $(2)$ & (3) & $(4)$ \\
\hline \multirow[t]{2}{*}{ Constant } & $-4,8208$ & $-0,1492$ & $-1,9981$ & 0,2581 \\
\hline & $(0,0000)$ & $(0,0070)$ & $(0,0000)$ & $(0,0560)$ \\
\hline \multirow[t]{2}{*}{ CRISIS } & $-0,8182$ & 0,0003 & $-0,3525$ & 0,0066 \\
\hline & $(0,0000)$ & $(0,9480)$ & $(0,0000)$ & $(0,3160)$ \\
\hline \multirow[t]{2}{*}{ SIZE } & 0,1513 & $-0,0040$ & 0,1622 & $-0,0224$ \\
\hline & $(0,0000)$ & $(0,0020)$ & $(0,0000)$ & $(0,0670)$ \\
\hline \multirow[t]{2}{*}{ DEBT } & 1,3564 & 0,3075 & 0,0254 & 0,1348 \\
\hline & $(0,0000)$ & $(0,0030)$ & $(0,6700)$ & $(0,2090)$ \\
\hline \multirow[t]{2}{*}{ EBTI } & & $-0,0720$ & & 0,3267 \\
\hline & & $(0,0480)$ & & $(0,2250)$ \\
\hline \multirow[t]{2}{*}{ ENF } & 0,0735 & 0,0027 & $-0,0039$ & 0,0017 \\
\hline & $(0,0000)$ & $(0,0010)$ & $(0,1970)$ & $(0,0340)$ \\
\hline \multirow[t]{2}{*}{ GDP } & $-0,1877$ & 0,0002 & $-0,1353$ & $-0,0030$ \\
\hline & $(0,0000)$ & $(0,8260)$ & $(0,0000)$ & $(0,0360)$ \\
\hline \multirow[t]{2}{*}{ INF } & $-0,2164$ & 0,0048 & $-0,0083$ & $-0,0018$ \\
\hline & $(0,0000)$ & $(0,0170)$ & $(0,7160)$ & $(0,4320)$ \\
\hline Dummy Country & Yes & Yes & Yes & Yes \\
\hline Dummy Sector & Yes & Yes & Yes & Yes \\
\hline Obs. & 2.620 & 2.620 & 11.210 & 11.210 \\
\hline Pseudo $\mathrm{R}^{2}$ & 0,1101 & & 0,0416 & \\
\hline Adjusted $\mathbf{R}^{2}$ & & 0,6538 & & 0,2169 \\
\hline F-statistic & & 2,09 & & 2,22 \\
\hline p-value & $(0,0000)$ & $(0,0083)$ & $(0,0000)$ & $(0,0042)$ \\
\hline
\end{tabular}

Note: p-values in brackets 
The results are also consistent with those obtained in the study by PricewaterhouseCoopers (2011), which revealed that most European listed companies did not recognize impairment losses in goodwill during the crisis. The findings are also in line with those obtained in the study by the European Securities and Markets Authority (2013), which, based on the year 2011, concluded that few companies recognized impairment losses in goodwill, with recognition for other intangible assets being even more limited. In fact, there is evidence of a certain level of conditional conservatism in the recognition of impairments by European listed companies (Amiraslani et al., 2013).

Thus, in periods of crisis, companies may use the discretion and subjectivity underlying asset impairment recognition with the aim of delivering better results and not jeopardizing their market position. Consequently, there is scope for earnings management practices to minimize the effects of the crisis.

Additionally, the literature suggests that the market reacts negatively to announcements of the recognition of impairment losses, since their recognition means that the expected future economic benefits of investments in assets will not be fully realized (Sant'Ana et al., 2016, among others), which may contribute to decisions to avoid recognizing impairments in periods of crisis.

The results also suggest that larger and more indebted firms, which are under tighter control and scrutiny, are more likely to recognize impairment losses. Also, firms in countries where the level of enforcement of accounting and auditing standards is higher are marginally less likely to recognize impairment losses. This impacts the quality of financial reporting, consistently with a stream of literature that argues that the quality of institutional factors, such as the level of investor protection, the efficiency of judicial systems and the level of enforcement of accounting and auditing standards, lead to higher quality financial reporting, specifically in the recognition of impairment losses (Glaum et al., 2015; Yammine \& Olivier, 2014).

The results of the comparative analysis between the companies from intervention and non-intervention countries reveal that the trend towards lower recognition of impairment losses in the crisis period occurs across all companies, reinforcing the previous findings. However, the results suggest a higher probability of not recognizing impairments in companies from intervention countries, where the greater scrutiny resulting from the intervention mitigates the opportunistic use of impairment recognition.

A higher tendency to avoid impairment recognition in the intervention countries is consistent with the results obtained in previous studies that have analysed goodwill impairment recognition in some of these countries, namely those of Albuquerque et al. (2011), Carvalho et al. (2013) and Izzo et al. (2013), which found that few firms recognized asset impairments during the crisis, and that some firms tended to postpone this recognition to the post-crisis period.

\subsection{Robustness analysis}

The results obtained are robust in terms of the absence of multicollinearity, as the correlations between the variables are low. Additionally, the large sample size adds asymptotic robustness to the data, and the residuals of the estimations performed follow the normality assumption.

Two additional analyses were also performed in order to assess the robustness of our main results. First, firms from the three most representative countries, the UK, France and Germany, were excluded from the sample. The results (not tabulated) are broadly similar to those obtained previously, reinforcing our main conclusion that there is a lower probability for the recognition of impairments in periods of crisis.

In the second analysis performed, only observations with impairments were considered. Again, consistently with the results of the main analysis, the CRISIS variable does not prove to be statistically significant (results not tabulated), thus we cannot conclude that the crisis affected the amount of impairments of European listed companies.

\section{Conclusions}

This study aimed to analyse the impact that the 2008-2009 financial crisis had on the recognition of impairments in non-financial assets by listed companies in the European Union. In addition, we analysed the particular case of countries that used the Economic and Financial Assistance Program (Ireland, Portugal, Spain, Italy and Greece), the so-called intervention countries.

The results suggest that European listed companies avoided recognizing asset impairments during the crisis period, which is in line with the findings of previous 
studies (Yammine \& Olivier, 2014; Zhang, 2011), and that the magnitude of impairments recognized was not affected by the crisis, consistently with the conclusions reached by Yammine and Olivier (2014). These results may indicate earnings management practices to improve reported results in order to offset the negative effect of the financial crisis on firms' performance. That is, managers may use the discretion underlying the recognition and calculation of impairments to manage earnings upward and thus mitigate the underperformance characteristic in times of crisis, counteracting the intended effects of measurement theory regarding the disclosure of financial statements in a way that facilitates economic decision making.

It is also concluded that during the financial crisis years, the probability of recognizing asset impairments was lower, regardless of whether the company belonged to an intervention country or not. However, it should be noted that during the crisis firms in countries that received financial aid were less likely to recognize impairments than those in non-intervention countries.

We contribute to the scarce literature that analyses the impact of the financial crisis on the recognition of impairments in non-financial assets and, in particular, in a context of greater financial fragility. We also contribute to the literature on the use of discretion in the recognition of impairments and earnings management practices, with the resulting impact on accounting information quality.

Given that in periods of financial crisis assets may not truly and reliably reflect their future economic benefits, this topic is of great importance in the current context of financial reporting and has relevant practical implications. Thus, the results of the study are of interest to the various stakeholders in the financial reporting process, namely: creditors, investors, financial market regulators, entities that prepare and oversee the application of accounting and auditing standards, and ultimately European leaders with respect to structural reforms and investor protection laws.

The main limitation of this study is the lack of data, namely the impossibility of disaggregating the value of impairments by nature of assets. As future research lines, it would be interesting to consider other variables, such as the company's share price and variables related to the corporate governance system, as well as further studying the influence of macroeconomic variables on the recognition of impairments. Additionally, it would be interesting to analyse the same topic in the context of unlisted companies, given their predominance in the European business structure.

\section{References}

AbuGhazaleh, N. M., Al-Hares, O., \& Roberts, C. (2011). Accounting discretion in goodwill impairments: UK evidence. Journal of International Financial Management \& Accounting, 22(3), 165-204.

Albuquerque, F., Almeida, C. A., \& Queirós, J. (2011). The impairment losses in non financial assets : Evidence from the Portuguese stock. International Journal of Business Research, 11 (2), 42-52.

Amiraslani, H., Iatridis, G. E., \& Pope, P. F. (2013). Accounting for asset impairment: A test for IFRS compliance across Europe. London: Cass Business School.

Barth, M. E., \& Landsman, W. R. (2010). How did financial reporting contribute to the financial crisis? European Accounting Review, 19(3), 399-423.

Bartram, S. M., \& Bodnar, G. M. (2009). No place to hide: The global crisis in equity markets in 2008/2009. Journal of International Money and Finance, 28(8), 1246-1292.

Bordo, M. D. (2008). An historical perspective on the crisis of 2007-2008 (NBER Working Paper No. 14569). Recuperado de https://www.nber.org/papers/w14569

Carvalho, C., Rodrigues, A. M., \& Ferreira, C. (2013, outubro). A relevância das perdas por imparidade do goodwill nos oito anos de aplicação das IAS/IFRS em Portugal. Anais do congresso internacional de contabilidade e auditoria, Lisboa, $L X, 15$.

Duh, R. R., Lee, W. C., \& Lin, C. C. (2009). Reversing an impairment loss and earnings management: The role of corporate governance. The International Journal of Accounting, 44 (2), 113-137.

Elliott, J., \& Shaw, W. (1988). Write-offs as accounting procedures to manage perceptions. Journal of Accounting Research, 26, 91-119.

European Securities and Markets Authority. (2013). European Enforcers Review of Impairment of Goodwill and 
other Intangible Assets in the IFRS Financial Statements. Paris: Autor.

Filip, A., \& Raffournier, B. (2014). The impact of the 2008-2009 financial crisis on earnings management: The European evidence. The International Journal of Accounting, 49 (4), 455-478.

Giner, B., \& Pardo, F. (2015). How ethical are managers' goodwill impairment decisions in Spanish-listed firms? Journal of Business Ethics, 132 (1), 21-40.

Glaum, M., Landsman, W. R., \& Wyrwa, S. (2015). Determinants of goodwill impairment under IFRS: International evidence. SSRN Electronic Journal, 1-54.

Gonçalves, T., \& Coelho, G. (2019). Earnings management during mergers and acquisitions: European evidence. European Journal of Economics, Finance and Administrative Sciences, 102, 22-43.

Gonçalves, T., Gaio, C., \& Lélis, C. (2020). Accrual mispricing: Evidence from European sovereign debt crisis. Research in International Business and Finance, 52, 101-111.

Gonçalves, T., Gaio, C., \& Santos, T. (2019). Women on board: Do they manage earnings? Empirical evidence from European listed firms. Review of Business Management, 21(3), 582-597.

Gonçalves, T., Gaio, C., \& Robles, F. (2018). The impact of working capital management on firm profitability in different economic cycles: Evidence from the United Kingdom. Economics and Business Letters, 7(2), 70-75.

Gunn, J. L., Khurana, I. K., \& Stein, S. E. (2018). Determinants and consequences of timely asset impairments during the financial crisis. Journal of Business Finance \& Accounting, 45(1-2), 3-39.

Hassine, N. M., \& Jilani, F. (2017). Determinants of goodwill impairment losses under IAS 36: The French case. International Journal of Accounting and Financial Reporting, 7(1), 88-102.

Hayn, C., \& Hughes, P. J. (2006). Leading indicators of goodwill impairment. Journal of Accounting, Auditing \& Finance, 21(3), 223-265.
Hope, O. K. (2003). Disclosure practice, enforcement of accounting standards and analyst' forecast accuracy: An international study. Journal of Accounting Research, 41(3), 235-272.

Houqe, M. N., Van Zijl, T., Dunstan, K., \& Karim, A. W. (2012). The effect of IFRS adoption and investor protection on earnings quality around the world. The International Journal of Accounting, 47(3), 333-355.

Huang, A. Y. (2013). To what extent does the European debt crisis affect both the European and the global economies? University of Kentucky, 1-28.

Izzo, M. F., Luciani, V., \& Sartori, E. (2013). Impairment of goodwill: Level of compliance and quality of disclosure during the crisis-an analysis of Italian listed companies. International Business Research, 6(11), 94-121.

Korošec, B., Jerman, M., \& Tominc, P. (2016). The impairment test of goodwill: an empirical analysis of incentives for earnings management in Italian publicly traded companies. Economic research-Ekonomska istraživanja, 29(1), 162-176.

Kousenidis, D. V., Ladas, A. C., \& Negakis, C. I. (2013). The effects of the European debt crisis on earnings quality. International Review of Financial Analysis, 30, 351-362.

Kvaal, E. (2005). Topics in accounting for impairment of fixed assets (Master's Dissertation). BI Norwegian School of Management, Norway.

Larson, K. D. (1969). Implications of measurement theory on accounting concept formulation. The Accounting Review, 44(1), 38-47.

Masruki, R., \& Azizan, N. A. (2012). The impact of Asian financial crisis to earnings management and operating performance in Malaysia. The Social Sciences, 7 (4), 510-516.

Pinto, I., Gaio, C., \& Gonçalves, T. (2019), Corporate governance, foreign direct investment, and bank income smoothing in African countries. International Journal of Emerging Markets, 15 (4), 670-690.

Preiato, J. P., Brown, P. R., \& Tarca, A. (2015). A comparison of between-country measures of legal setting 
and enforcement of accounting standards. Journal of Business Finance \& Accounting, 42(1), 1-50.

PriceWaterhouseCoopers (2011). Making acquisitions transparent: Goodwill accounting in times of crisis. Frankfurt. Recuperado de https://www.yumpu.com/ en/document/read/10765482/making-acquisitionstransparent-goodwill-accounting-in-times-of-

Ramanna, K., \& Watts, R. L. (2012). Evidence on the use of unverifiable estimates in required goodwill impairment. Review of Accounting Studies, 17(4), 749-780.

Riedl, E. J. (2004). An examination of long-lived asset impairments. The Accounting Review, 79 (3), 823-852.

Saastamoinen, J., \& Pajunen, K. (2016). Goodwill impairment losses as managerial choices. International Journal of Managerial and Financial Accounting, 8(2), 172-195.

Sant'Ana, F., Gonçalves, J., Guerreiro, C., \& Nobre, L. (2016). Perdas por imparidade: Fatores explicativos e impactos. Revista Brasileira de Gestão de Negócios, 18(60), 305-317.

Strong, J., \& Meyer, J. (1987). Asset write-downs: Managerial incentives and security returns. Journal of Finance, 42(3), 643-663.
Vanza, S., Wells, P., \& Wright, A. (2011). Asset impairment and the disclosure of private information. Journal of Contemporary Accounting and Economics, 14(2018), 22-40.

Verriest, A., \& Gaeremynck, A. (2009). What determines goodwill impairment? Review of Business and Economics, 54(2), 1-23.

Wirtz, D. (2013). An analysis of the usefulness to investors of managers' fair value estimates of firm assets: Evidence from IAS 36 "Impairment of Assets" and IAS 40 "Investment Property." (Doctoral Thesis). Faculty of Economics and Business - FEB, Amsterdam, Netherlands.

Yammine, M., \& Olivier, H. (2014, abril). Enforcement of accounting standards, financial crisis, and their impact on impairment of non-financial assets. Conferência Comercial do Hemisfério Ocidental, Laredo, Estados Unidos da América, 18.

Zhang (2011). Determinants of goodwill impairment: Investigation of German and UK listed firms. (Tese de Mestrado). Universiteit van Amsterdam, Amsterdam, Holanda. 


\section{Appendix \\ Variables description}

\begin{tabular}{|c|c|c|c|}
\hline Variables & Definition & Expected Sign & Support Literature \\
\hline \multicolumn{4}{|c|}{ Dependent variables } \\
\hline IMP DUM & $\begin{array}{l}\text { Dummy variable that assumes the value } 1 \text { when } \\
\text { the company recognizes impairment in assets } \\
\text { (tangible and intangible, including goodwill), } \\
\text { and the value } 0 \text { otherwise. }\end{array}$ & & Yammine \& Olivier (2014). \\
\hline RATIO IMP & $\begin{array}{l}\text { Ratio between total asset impairment (tangible } \\
\text { and intangible, including goodwill), net of } \\
\text { impairment reversals, and total underlying assets. }\end{array}$ & & Yammine \& Olivier (2014). \\
\hline \multicolumn{4}{|c|}{ Independent variables } \\
\hline CRISIS & $\begin{array}{l}\text { Crisis: dummy variable that assumes the value } \\
1 \text { if the observation belongs to the crisis period } \\
\text { (2008 and 2009), and the value } 0 \text { otherwise. }\end{array}$ & - & $\begin{array}{l}\text { Hassine \& Jilani (2017); Filip \& } \\
\text { Raffournier, 2014; Zhang (2011); Barth } \\
\text { \& Landsman, 2010; Bartram \& Bodnar, } \\
\text { 2009. }\end{array}$ \\
\hline SIZE & Size: natural logarithm of total assets. & + & $\begin{array}{l}\text { Sant'Ana et al. (2016); Giner \& Pardo } \\
\text { (2015); Ramanna \& Watts (2012). }\end{array}$ \\
\hline DEBT & $\begin{array}{l}\text { Indebtedness: ratio between total debt and total } \\
\text { assets. }\end{array}$ & $+1-$ & $\begin{array}{l}\text { Hassine \& Jilani (2017). Koroš.ec et al. } \\
\text { (2016); Saastamoinen \& Pajunen (2016); } \\
\text { Ramanna \& Watts (2012). }\end{array}$ \\
\hline EBTI & $\begin{array}{l}\text { Earnings Before Tax - Adjusted: ratio between } \\
\text { earnings before tax, adjusted for impairments } \\
\text { and reversals for the year, and total assets. }\end{array}$ & - & $\begin{array}{l}\text { Yammine \& Olivier (2014); Kvaal } \\
\text { (2005). }\end{array}$ \\
\hline ENF & $\begin{array}{l}\text { Enforcement: index created based on } \\
\text { Preiato et al. (2015), for the year 2008, which } \\
\text { reflects the level of enforcement of accounting } \\
\text { and auditing standards. }\end{array}$ & - & $\begin{array}{c}\text { Glaum (2015); Yammine \& Olivier } \\
\text { (2014). }\end{array}$ \\
\hline GDP & Gross Domestic Product: real GDP growth rate. & - & Yammine \& Olivier (2014). \\
\hline INF & Inflation: inflation growth rate. & - & Yammine \& Olivier (2014). \\
\hline SET & $\begin{array}{l}\text { Represents the set of dummy variables for each } \\
\text { sector and assumes the value } 1 \text { if the company } \\
\text { belongs to the respective sector, and } 0 \text { otherwise } \\
\text { (classification of sectors according to Table } 2 \text { ). }\end{array}$ & n.a. & Yammine \& Olivier (2014). \\
\hline COUNTRY & $\begin{array}{l}\text { Represents the set of dummy variables for each } \\
\text { country and assumes the value } 1 \text { if the company } \\
\text { belongs to that country, and } 0 \text { otherwise. }\end{array}$ & n.a. & Yammine \& Olivier (2014). \\
\hline
\end{tabular}




\section{Financial support:}

We gratefully acknowledge the financial support from FCT- Fundação para a Ciencia e Tecnologia (Portugal), and national funding through research grant UIDB/04521/2020.

\section{Conflicts of interest:}

The authors have no conflict of interest to declare.

\section{Copyrights:}

RBGN owns the copyrights of this published content.

\section{Plagiarism analysis:}

RBGN performs plagiarism analysis on all its articles at the time of submission and after approval of the manuscript using the iThenticate tool.

\section{Authors:}

1. Cristina Gaio, PhD, Advance/CSG, ISEG, University of Lisbon, Lisbon, Portugal.

E-mail: cgaio@iseg.ulisboa.pt

2. Tiago Gonçalves, PhD, Advance/CSG, ISEG, University of Lisbon, Lisbon, Portugal.

E-mail: tiago@iseg.ulisboa.pt

3. Anabela Pereira, Master's Degree, ISEG, University of Lisbon, Lisbon, Portugal.

E-mail: anabela_dpereira@hotmail.com

\section{Authors' Contributions:}

1. Cristina Gaio: Definition of research problem; Development of hypotheses or research questions (empirical studies); Definition of methodological procedures; Literature review; Statistical analysis; Analysis and interpretation of data; Critical revision of the manuscript; Manuscript writing.

2. Tiago Gonçalves: Definition of research problem; Development of hypotheses or research questions (empirical studies); Definition of methodological procedures; Literature review; Statistical analysis; Analysis and interpretation of data; Critical revision of the manuscript; Manuscript writing.

3. Anabela Pereira: Data Collection; Statistical analysis; Analysis and interpretation of data; Manuscript writing. 